\title{
Effect in vitro on platelet function of two compounds developed from the pyrimido-pyrimidines
}

\author{
S. D. Slater, A. G. G. TURPIE, A. S. DOUGlas, AND G. P. McNiCOL \\ From the University Department of Medicine, Royal Infirmary, Glasgow
}

SYNOPSIS VK 774 and VK 744, two new compounds developed from the pyrimido-pyrimidines, have been found to be powerful inhibitors of platelet function tested in vitro. They inhibit adenosine diphosphate (ADP)-induced platelet aggregation, and the release of platelet factor 3 by kaolin, and VK 774 also reduces platelet adhesiveness and inhibits platelet aggregation ('snowstorm' effect) in the Chandler tube system. Although measured percentage whole blood clot retraction was uninfluenced by these drugs the clot produced with VK 774 was friable and soft. VK 774 appears to be the most powerful of these compounds reported so far, being active in some test systems at $10^{-6} \mathrm{M}$, and, if the results of toxicity testing are satisfactory, it should be an important agent for therapeutic trial.

Platelets play a major role in the initiation of thrombus formation and this is particularly true of thrombi arising on the arterial side of the circulation (Mustard and Packham, 1970a). Platelet function may be studied in a number of systems in vitro and the effect of various drugs thereby assessed. The pyrimidopyrimidine derivatives have been widely studied in this respect but many other compounds interfering with platelet action have been described and the subject has recently been reviewed by Mustard and Packham (1970b). The early pyrimido-pyrimidine derivative dipyridamole (RA8, Persantin, Boehringer Ingelheim, Limited) was found to be effective in vitro in inhibiting platelet aggregation induced by ADP (Emmons, Harrison, Honour, and Mitchell, 1965a; Gray, Wilson, and Douglas, 1968), platelet aggregation in the Chandler tube system, and platelet adhesiveness (Gray et al, 1968). Dipyridamole has also been demonstrated to inhibit thrombus forming at sites of vascular injury in experimental animals (Emmons, Harrison, Honour, and Mitchell, 1965b; Didisheim, 1968), and in a controlled trial with random allocation has been shown to be of value when combined with oral anticoagulants in reducing the incidence of embolic episodes in patients with prosthetic heart valves as compared with patients on anticoagulants alone (Sullivan, Harken, and Gorlin, 1969). Since the introduction of dipyridamole, other pyrimido-pyrimidine derivatives have been developed and found in certain in-vitro systems to inhibit Received for publication 19 October 1971. platelet function more powerfully. RA 433 was found to be a more potent inhibitor of ADP-induced platelet aggregation in vitro than dipyridamole (Elkeles, Hampton, Honour, Mitchell, and Prichard, 1968; Forbes, McNicol, and Douglas, 1969) but had no effect on thrombus formation in the experimental animal (Elkeles et al, 1968). RA 233 in turn, in a direct comparison with RA 433, has been found to be the more powerful inhibitor of ADP-induced platelet aggregation, of platelet aggregation induced by calcium in a turbidimetric system, and of platelet adhesiveness (Hassanein, Turpie, McNicol, and Douglas, 1970).

This study deals with the effect upon human platelet function in vitro of two new compounds, VK 774 and VK 744 , chemically distinct from but historically related to pyrimido-pyrimidine derivatives. Their activity in this respect is directly compared with the pyrimido-pyrimidine derivative RA 233.

\section{Chemistry}

VK 774 is 4-morpholino-2-piperazino-thieno-(3, 2-D) pyrimidine-dihydrochloride, and VK 744 is 2-((2 aminoethyl)amino)-4-morpholinothieno (3, 2-D)pyrimidine-dihydrochloride, and their structural formulae together with those of RA 233 and RA 8 (dipyridamole)are set out on page 2. Both VK 774 and VK 744 are soluble in water and their molecular weights are $432 \cdot 39$ and $352 \cdot 30$ respectively. RA 233 is 


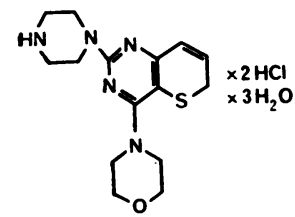

VK 774

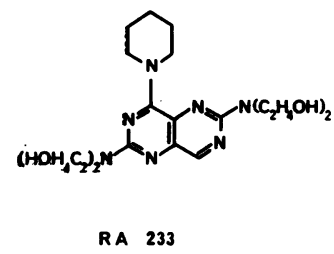

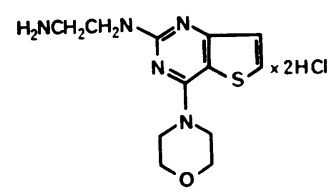

VK 744

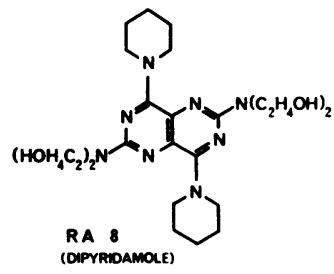

relatively insoluble in water but soluble in dilute acids; its molecular weight is $421 \cdot 50$.

\section{Materials}

VK 774 (BOEHRINGER INGELHEIM, LIMITED)

Stock solutions are $10^{-2} \mathrm{M}$ and $10^{-3} \mathrm{M}$ VK 774 in sterile distilled water, stored at $4^{\circ} \mathrm{C}$. Dilutions referred to in the text were made in sterile distilled water.

VK 744 (BOEHRINGER INGELHEIM, LIMITED) Stock solutions are $10^{-2} \mathrm{M}$ and $10^{-3} \mathrm{M}$ VK 744 in sterile distilled water, stored at $4^{\circ} \mathrm{C}$. Dilutions referred to in the text were made in sterile distilled water.

\section{RA 233 (BOEHRINGER INGELHEIM, LIMITED)}

Stock solutions are $10^{-2} \mathrm{M}$ and $10^{-3} \mathrm{M}$ RA 233 in $0.025 \mathrm{~N} \mathrm{HCl}$, stored at $4^{\circ} \mathrm{C}$. Dilutions referred to in the text were made in $0.025 \mathrm{~N} \mathrm{HCl}$.

\section{ADENOSINE 5-DIPHOSPHATE (ADP) (SIGMA} CHEMICAL COMPANY, ST LOUIS)

Stock solution of $100 \mu \mathrm{g} / \mathrm{ml}$ ADP in barbitone/saline buffer, $p \mathrm{H} 7 \cdot 2$; stored at $-20^{\circ} \mathrm{C}$. Dilutions were made in barbitone/saline buffer.

\section{TUBING}

In Chandler tube experiments transparent vinyl tubing (N/17, Portland Plastics Limited, Kent) and plastic adaptors $(10 \mathrm{M} / 634$, Portex) were used.

\section{GLASS BEAD COLUMNS}

Transparent vinyl tubing (NT/13, Portland Plastics Limited, Kent) and translucent silicone tubing (Esco Rubber Limited, London) were used.
Ballotini glass beads, $0.57 \mathrm{~mm}$ diameter; calcium chloride, $0.25 \mathrm{M}, 0.025 \mathrm{M}$; kaolin, $5 \%$ kaolin in imidazole buffered saline $p \mathbf{H ~ 7 . 2}$; Russell viper venom (Stypven, Burroughs Wellcome Company).

Citrated blood was collected by clean venepuncture in plastic syringes with 21 -gauge needles, 9 volumes of blood being mixed with 1 volume of $3.8 \%$ trisodium citrate in siliconized graduated centrifuge tubes maintained at room temperature. Platelet-rich plasma was obtained by centrifugation of citrated whole blood at $600 \mathrm{~g}$ for five minutes at room temperature. Siliconized glassware was used throughout (Siliclad, Clay-Adams, Inc, New Jersey).

\section{Methods}

The following parameters of platelet function were studied and the methods are described in detail by Forbes et al (1969).

\section{ADP-INDUCED PLATELET AGGREGATION}

This was studied by the method of Born (1962) at room temperature. Platelet-rich plasma $(1.8 \mathrm{ml})$ was incubated at room temperature for five minutes with $0.2 \mathrm{ml}$ dilutions of test solution or with solvent control, and challenged by $0.5 \mu \mathrm{g}$ of ADP (final concentration $0.24 \mu \mathrm{g} \mathrm{ADP} / \mathrm{ml}$ solution). The optical density was recorded every 10 seconds for 10 minutes after addition of ADP.

Indices of platelet aggregation and disaggregation are expressed as follows: $30-60$ platelet aggregation is fall in optical density between 30 and 60 seconds after the addition of ADP; maximum aggregation is the difference between the lowest recorded optical density and the constant arbitrary baseline of 0.600 ; percentage disaggregation is the ratio between the increment in optical density occurring in five minutes from the point of maximum aggregation and the maximum platelet aggregation.

\section{PLATELET ADHESIVENESS}

The glass bead column technique of Hellem (1960) as modified by Hirsh, McBride: and Dacie (1966) was used. Citrated whole blood $(4.0 \mathrm{ml})$ was incubated at room temperature for 10 minutes with $0.04 \mathrm{ml}$ of test solution or control.

RELEASE OF PLATELET FACTOR 3 BY KAOLIN A modification of the technique of Spaet and Cintron (1965) was used. Platelet-rich plasma (0.9 ml) was preincubated at $37^{\circ} \mathrm{C}$ for 10 minutes with test dilutions or solvent control $(0 \cdot 1 \mathrm{ml})$.

\section{CHANDLER TUBE TECHNIQUE}

The method used was that described by Chandler (1958) as modified by Cunningham, McNicol, and 
Douglas (1965). Small volumes were used: plateletrich plasma $(1.0 \mathrm{ml}), 0.877 \%$ saline $(2.86 \mathrm{ml})$, and test solution or solvent control $(0.04 \mathrm{ml})$ were incubated in the Chandler tube at $37^{\circ} \mathrm{C}$ for five minutes before recalcification with $0.25 \mathrm{M}$ calcium chloride $(0.1 \mathrm{ml})$.

\section{WHOLE BLOOD CLOT RETRACTION}

A modification of the method described by Dacie and Lewis (1968) was used; whole blood $(4.95 \mathrm{ml})$ was mixed in siliconized centrifuge tubes containing copper wire spirals with test solution or solvent control $(0.05 \mathrm{ml})$ before clot formation.

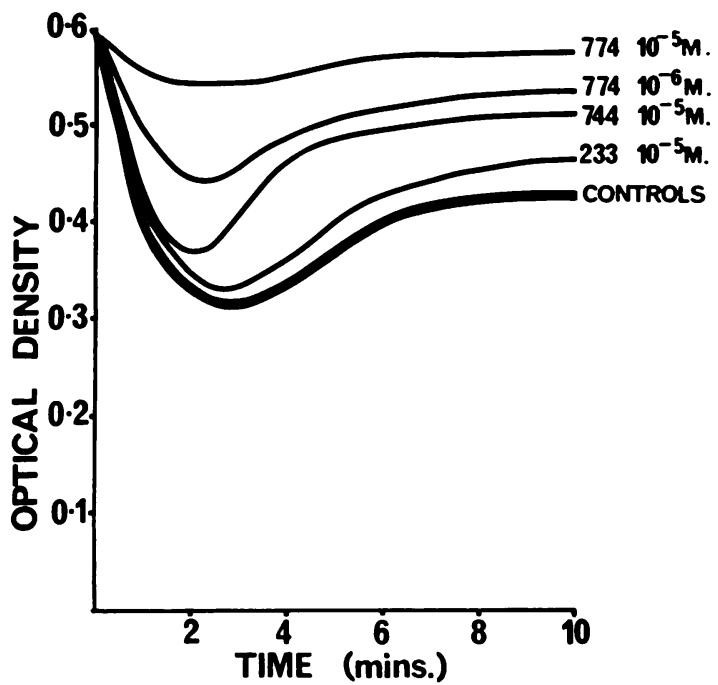

Fig. 1 ADP-induced platelet aggregation. Results of 14 experiments using VK 774, VK 744, and RA 233 at a concentration of $10^{-5} \mathrm{M}$, and of seven experiments at a concentration of $10^{-6} \mathrm{M}$ (VK 774 only shown) compared with solvent controls. ADP concentration $0.24 \mu \mathrm{g} / \mathrm{ml}$.
Platelet counts were performed with formal-citrate as the diluting fluid (Dacie and Lewis, 1968).

\section{Results}

\section{ADP-INDUCED PLATELET AGGREGATION}

In 14 experiments both VK 774 and VK 744 produced statistically significant inhibition of 30 to 60 sec and maximal platelet aggregation at a final concentration of $10^{-5} \mathrm{M}$, though VK 774 was the more powerful $(P<0.001)$ and almost completely inhibited aggregation. VK 744 also produced a significant increase in percentage disaggregation $(\mathrm{P}<0.001)$. RA 233 at this concentration $\left(10^{-5} \mathrm{M}\right)$ had no significant effect on 30 to $60 \mathrm{sec}$ or maximum platelet aggregation but significantly increased percentage disaggregation $(\mathrm{P}<0.001)$, although VK 744 was more powerful in this respect $(P<0.001)$. In seven experiments at a concentration of $10^{-6} \mathrm{M}$, of the three drugs, only VK 774 had a statistically significant effect in the system, producing inhibition of 30 to $60 \mathrm{sec}$ aggregation $(0.01>P>$ 0.001 ) and of maximum platelet aggregation $(P<0.001)$. Figure 1 shows the mean results of the three drugs in the 14 experiments at $10^{-5} \mathrm{M}$ concentration, and of the effect of VK 774 at $10^{-6} \mathrm{M}$ concentration compared with solvent controls.

\section{PLATELET ADHESIVENESS}

In seven experiments at a final concentration of $10^{-5} \mathrm{M}$ VK 774 significantly reduced retention of platelets by glass beads $(P<0.001)$, but VK 744 and RA 233 had no statistically significant effect at this concentration. These results are shown in Figure 2.

\section{RELEASE OF PLATELET FACTOR 3 BY KAOLIN} In seven experiments at a concentration of $10^{-5} \mathrm{M}$ all three drugs produced statistically significant reduc-

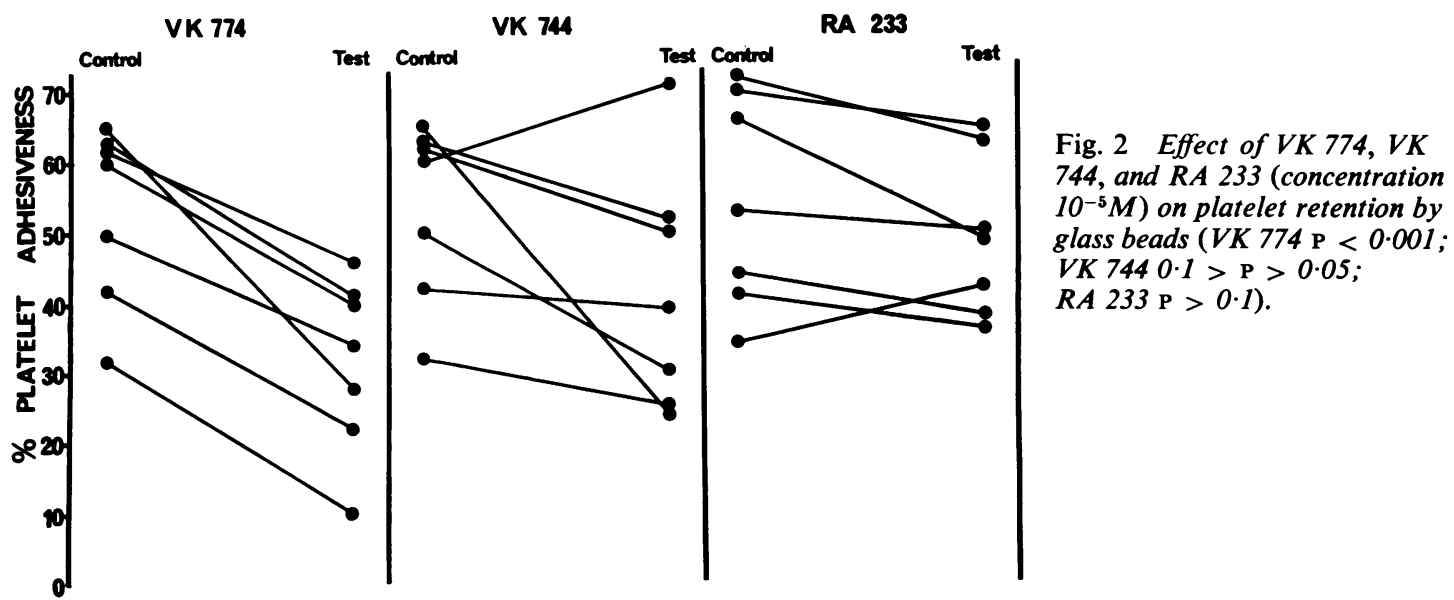

Fig. 2 Effect of $V K$ 774, $V K$ 744 , and RA 233 (concentration $10^{-5} \mathrm{M}$ ) on platelet retention by $V K 7440.1>\mathrm{P}>0.05$; $R A 233 \mathrm{P}>0 \cdot 1)$. 

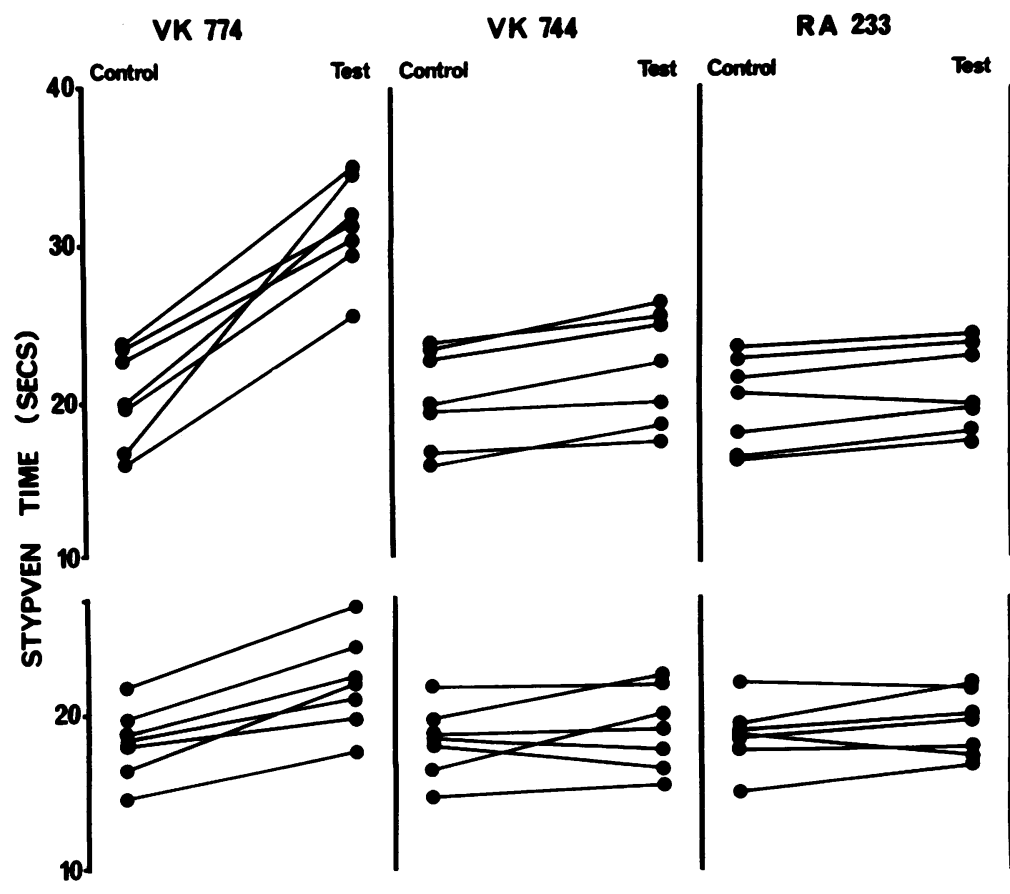

Fig. 3 Effect of two concentrations of $V K$ 774, $V K 744$, and of $R A 233$ on the release of platelet factor 3 by kaolin. (Above, concentration $10^{-5} M, V K$ 774, $\mathrm{P}<0.001$; $V K 7440.01>\mathrm{P}>0.001$; RA $2330.05>\mathrm{P}>0.02$. Below, concentration $10^{-6} \mathrm{M}, \mathrm{VK} 774$ $\mathrm{P}<0.001 ;$ VK $744 \mathrm{P}>0.1$; $R A 233 \mathrm{P}>0 \cdot 1$.) tion in platelet factor 3 release. VK 774 was more potent in this respect than VK $744(P=0.001)$, which in turn was more powerful than RA 233 $(0.01>P>0.001)$. At a concentration of $10^{-6} \mathrm{M}$ in seven experiments only VK 774 had a statistically significant effect $(P<0.001)$. These results are shown in Figure 3.

\section{CHANDLER TUBE TECHNIQUE}

The results obtained in seven experiments using VK 774, VK 744, and RA 233 at a final concentration of $10^{-4} \mathrm{M}$ compared with solvent controls are shown in Figure 4. VK 774 and RA 233 produced significant prolongation of platelet aggregation time ('snowstorm' effect). They also considerably reduced the $\underset{\propto}{\stackrel{\perp}{\complement}}$ magnitude of the snowstorm effect as judged by $\overrightarrow{\vec{F}}$ inspection; this action was particularly noticeable $\frac{}{3}$ with VK 774. VK 744 had no significant effect in this system.

\section{WHOLE BLOOD CLOT RETRACTION} In seven experiments at $10^{-4} \mathrm{M}$ concentration VK 774, VK 744, and RA 233 had no statistically significant effect on percentage clot retraction although some of the clots with VK 774 were noted to be friable and soft.

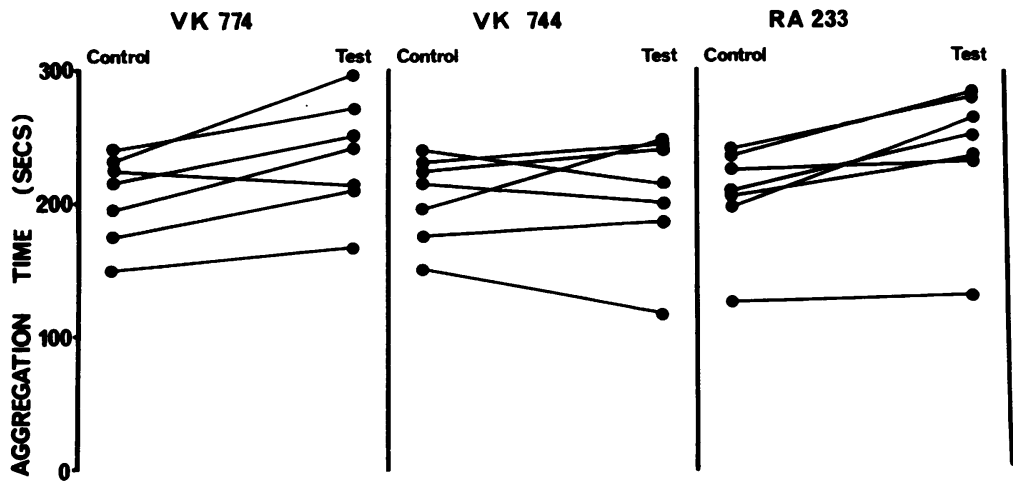

Fig. 4 Effect of $V K$ 774, $V K$ 744 , and $R A 233$ in concentrations of $10^{-4} \mathrm{M}$ on platelet aggregation time in the Chandler tube system (VK 774 0.0.02; > P > 0.01; $V K 744 \mathrm{P}>0 \cdot 1 ; R A 233$ $0.01>\mathrm{P}>0.001$ ). 


\section{Discussion}

The first step in the initiation of thrombus formation is the adherence and aggregation of platelets to each other and to the vessel wall (Mustard, Murphy, Rowsell, and Downie, 1962), and ADP released into the blood stream by various mechanisms appears to play a major part in stimulating this process (Mustard and Packham, 1970a). Subsequent release of platelet factor 3 (phospholipoprotein), promoted by platelet aggregation (Mustard, Hegardt, Rowsell, and MacMillan, 1964; Hardisty and Hutton, 1966), accelerates the clotting mechanism and leads to stabilization of the thrombus with fibrin production, and eventual clot retraction reduces the friability of the clot. Substances capable of inhibiting platelet adhesion and aggregation, release of platelet factor 3 , and clot retraction, may be expected to be of possible therapeutic value. Which particular platelet function test best reflects the thrombus-forming properties of a platelet is, however, unknown, and tests in vivo using the injured artery model are not necessarily more valid than tests in vitro (Elkeles et al, 1968). A useful review of platelet function tests and their relevance to thrombosis has been given by Hampton (1967).

The place of anticoagulant therapy in arterial thrombosis remains controversial. Platelet behaviour, of central importance in the initiation of thrombi, especially arterial, is largely uninfluenced by anticoagulant drugs. Drugs such as the pyrimidopyrimidine derivatives which interfere with platelet function, however, offer a potential therapeutic advance in the management of arterial thrombosis, and there is already clinical and experimental evidence of the usefulness of dipyridamole in the prevention of thromboembolic complications of prosthetic heart valves (Sullivan et al, 1969; Harker and Slichter, 1970). So far neither RA 433 nor RA 233 have been evaluated clinically though they are well absorbed orally and appear to be relatively nontoxic in experimental animals (Elkeles et al, 1968; Hassanein et al, 1970). VK 774 and VK 744 are two new compounds developed from the pyrimidopyrimidines and their effect on platelet function in vitro is reported and compared directly with that of RA 233. VK 774 and VK 744 inhibit ADP-induced platelet aggregation and VK 774 is considerably more powerful in this respect, almost completely inhibiting aggregation at $10^{-5} \mathrm{M}$ and being the only drug still significantly effective at $10^{-6} \mathrm{M}$. VK 744 , and to a significantly lesser degree RA 233, increase platelet disaggregation though there is no significant effect on aggregation by RA 233 at the concentrations used. Platelet adhesiveness is significantly reduced only by VK 774, VK 744, and RA 233 having no significant effect at the concentration used.
All three drugs impair the release of platelet factor 3 by kaolin, the VK compounds proving more potent in this respect than RA 233, and VK 774 having statistically the most powerful effect. At a concentration of $10^{-6} \mathrm{M}$ again only VK 774 has a statistically significant inhibitory effect on platelet factor 3 release. Platelet aggregation in the Chandler tube system, as estimated by the time of appearance of the snowstorm effect of aggregation, is significantly inhibited by VK 774 and RA 233 but not by VK 744 . There is no significant difference noted between VK 774 and RA 233. They both also considerably reduce the magnitude of the snowstorm effect and this is particularly noticeable with VK 774 with which clotting occurs with little or no recognizable prior snowstorm effect of platelet aggregation. In the concentration used there is no effect on percentage whole blood clot retraction by any of the three drugs although the final clot with VK 774 is noted in some cases to be friable and soft.

These results show that VK 774 and VK 744 have anti-platelet properties similar to the previously tested pyrimido-pyrimidine derivatives RA 233, RA 433, and dipyridamole, and in some of the invitro systems tested are significantly more powerful. Of the two VK compounds tested, VK 774 stands out clearly in this study to be considerably the more potent drug and therefore the most powerful of these compounds so far reported. Initial toxicity studies with VK 774 are promising, and if these are satisfactorily completed it should be an important agent for therapeutic trial.

We are grateful to Professor E. M. McGirr for his interest in this work. Financial support was provided by the Medical Research Council, Boehringer Ingelheim Limited, and FBA Pharmaceuticals.

Dr John Bell, of Boehringer Ingelheim Limited, kindly provided the VK 774, VK 744, and RA 233 used in this study.

\section{References}

Born, G. V. R.(1962). Quantitative investigations into the aggregation of blood platelets. J. Physiol. (Lond.), 162, 67P-68P.

Chandler, A. B. (1958). In vitro thrombotic coagulation of the blood: a method for producing a thrombus. Lab. Invest., 7, 110-114.

Cunningham, G. M., McNicol, G. P., and Douglas, A. S. (1965). Effect of anti-coagulant drugs on platelet aggregation in the Chandler's tube. Lancet, 1, 729-730.

Dacie, J. V., and Lewis, S. M. (1968). Practical Haematology, 4th Ed., pp. 70-71, and 319-320. Churchill, London.

Didisheim, P. (1968). Inhibition by dipyridamole of arterial thrombosis in rats. Thrombos. Diathes. haemorrh. (Stuttg.), 20, 257-266.

Elkeles, R. S., Hampton, J. R., Honour, A. J., Mitchell, J. R. A., and Prichard, J. S. (1968). Effect of a pyrimido-pyrimidine compound on platelet behaviour in vitro and in vivo. Lancet, 2, 751-754.

Emmons, P. R., Harrison, M. J. G., Honour, A. J., and Mitchell, J. R. A. (1965a). Effect of dipyridamole on human platelet behaviour. Lancet, 2, 603-606.

Emmons, P. R., Harrison, M. J. G Honour, A. J., and Mitchell, 
J. R. A. (1965b). Effect of a pyrimidopyrimidine derivative on thrombus formation in the rabbit. Nature (Lond.), 208, 255-257.

Forbes, C. D., McNicol, G. P., and Douglas, A. S. (1969). Action of a pyrimido-pyrimidine compound on platelet behaviour in vitro. Brit. med. J., 2, 483-485.

Gray, G. R., Wilson, P. A., and Douglas, A. S. (1968). The effect of dipyridamole on platelet aggregation and adhesiveness. Scot. med. J., 13, 409-415.

Hampton, J. R. (1967). The study of platelet behaviour and its relevance to thrombosis. J. Atheroscler. Res., 7, 729-746.

Hardisty, R. M., and Hutton, R. A. (1966). Platelet aggregation and the availability of platelet factor 3. Brit. J. Haemat., 12, 764-776.

Harker, L. A., and Slichter, S. J. (1970). Studies of platelet and fibrinogen kinetics in patients with prosthetic heart valves. New Engl. J. Med., 283, 1302-1305.

Hassanein, A. A., Turpie, A. G. G., McNicol, G. P., and Douglas, A.S. (1970). Effect of RA233 on platelet function in vitro. Brit. med. J., 2, 83-86.

Hellem, A. J. (1960). The adhesiveness of human blood platelets in vitro. Scand. J. clin. Lab. Invest., 12, Suppl. 51.
Hirsh, J., McBride, J. A., and Dacie, J. V. (1966). Thrombo-embolism and increased platelet adhesiveness in post-splenectomy thrombocytosis. Aust. Ann. Med., 15, 122-128.

Mustard, J. F., Hegardt, B., Rowsell, H. C., and MacMillan, R. L. $\overrightarrow{\bar{C}}$ (1964). Effect of adenosine nucleotides on platelet aggregation and clotting time. J. Lab. clin. Med., 64, 548-559.

Mustard, J. F., Murphy, E. A., Rowsell, H. C., and Downie, H. G. (1962). Factors influencing thrombus formation in vivo. Amer. $\bar{\omega}$ J. Med., 33, 621-647.

Mustard, J. F., and Packham, M. A. (1970a). Thromboembolism: a manifestation of the response of blood to injury. Circulation,

Mustard, J. F., and Packham, M. A. (1970b). Factors influencing platelet function: adhesion, release, and aggregation. Pharmacol. Rev., 22, 97-187.

Spaet, T. H., and Cintron, J. (1965). Studies on platelet factor 3 availability. Brit. J. Haemat., 11, 269-275.

Sullivan, J. M., Harken, D. E., and Gorlin, R. (1969). Effect of dipyridamole on the incidence of arterial emboli after cardiac $\square$ valve replacem.ent. Circulation, 39-40, Suppl. 1, 149-153.

\section{The April 1972 Issue}

\section{THE APRIL 1972 ISSUE CONTAINS THE FOLLOWING PAPERS}

Quantitative observations on mineralized and nonmineralized bone in the iliac crest H. A. ELLIS AND KATHLEEN M. PEART

Aortic disease in idiopathic retroperitoneal and mediastinal fibrosis M. J. MITCHINSON

The diagnosis of Hodgkin's disease in surgically excised spleens GEOFFREY FARRER-BROWN, M. H. BENNETT, C. V. HARRISON, YVONNE MILLETT, AND A. M. JELLIFFE

Adenoid basal carcinoma of the cervix uteri K. B. SHILKIN

Angiofollicular lymph node hyperplasia (Castleman) DIMITRA ANAGNOSTOU AND C. V. HARRISON

Histological and ultrastructural findings in a case of the Sézary syndrome J. J. LABAzE, E. A. MOSCOVIC, T. D. PHAM, AND H. A. AZAR

A simple assay of intrinsic factor-vitamin $\mathbf{B}_{12}$ complex employing the binding intrinsic factor antibody ELIZABETH JACOB AND H. A. W. O'BRIEN

An immunoradiometric assay for ferritin in the serum of normal subjects and patients with iron deficiency and iron overload G. M. ADDISON, M. R. BEAMISH, C. N. HALES, M. HODGKINS, A. JACOBS, AND P. LLEWELLIN

An automated screening technique for the detection of sickle-cell haemoglobin D. M. CANNING, R. S. CRANE, R. G. HUNTSMAN, AND G. I. YAWSON

Methods for improving the sensitivity and specificity of the fibrin plate NEIL EDWARD

Data processing in hospital bacteriology: experience of 18 months' trial J. L. WHITBY AND JANET N. BLAIR
The relationship between fluorescent, agglutinating, $\bar{z}$ and precipitating antibodies to Candida albicans and their immunoglobin classes T. LEHNER, HELEN R. BUCKLEY, AND I. G. MURRAY

A rapid automated screening technique for the detection of placental-like alkaline phosphatase in malignant disease R. C. JENNINGS, D. BROCKLEHURST, AND M. HIRST

The relation of growth hormone to altered carbohydrate metabolism in women taking oral contraceptives D. S. J. MAW AND VICTOR WYNN

\section{Present day practice}

An assessment of a latex agglutination slide test for toxoplasma antibody W. KWANTES, R. A. PAYNE, G. B. LUDLAM, J. B. BRIDGES, AND D. G. FLECK

\section{Technical methods}

A quick method for the isolation of glomeruli from human kidney A. H. NAGI AND W. KIRKWOOD

Cultivation of human embryonic liver cells in disposable microplates MARIE A. BRYCESON, PATRICIA E. TAYLOR, AND A. J. ZUCKERMAN

Storage of lymphocytes for immunological study T. M. BELL, E. A. CASPARY, AND E. J. FIELD

A safe and inexpensive method for setting up the Westergren ESR A. K. RAY

Golgi method for old formol-fixed human foetal tissue DOROTHY MEYER AND SERGE DUCKETT

Letters to the Editor

Book reviews

Conferences

Copies are still available and may be obained from the PUBLISHING MANAGER, BRITISH MEDICAL ASSOCIATION, TAVISTOCK SQUARE, LONDON, WC1H 9JR, price $£ 1.05$ 